Arkadiusz Adamczyk

\title{
MIEJSCE REPUBLIK ZWIĄZKOWYCH ZSRS (BIAŁORUŚ, ESTONIA, LITWA, ŁOTWA, UKRAINA) W ROZWAŻANIACH POLSKICH ŚRODOWISK POLITYCZNYCH, INTELEKTUALNYCH I KULTURALNYCH W LATACH 1945-1989
}

Uwzględnienie obecności państw bałtyckich i krain kresowych, przede wszystkim Ukrainy i w mniejszym stopniu Białorusi, w rozważaniach polskich intelektualistów w okresie poprzedzającym wybuch II wojny światowej, jak również w jej trakcie, było traktowane jako oczywistość. Sąsiedzi Rzeczypospolitej budzili zrozumiałe zainteresowanie przede wszystkim z racji swej bliskości, stając się stałym elementem rozważań antropologicznych, historycznych, geograficznych i kulturowych. Ziemie wschodnie stały się też przedmiotem implementowanym do wielkich koncepcji geopolitycznych, kreowanych głównie przez przedstawicieli lewicy niepodległościowej i otoczenia Józefa Piłsudskiego.

Wydarzenia lat 1918-1923 sprawily, iż projekty te stracily na aktualności. W kwestii ziem białoruskich i ukraińskich ostateczne rozstrzygnięcie przyniósł traktat zawarty 18 marca 1921 r. w Rydze między Rzecząpospolitą Polską a (oficjalnie) republikami socjalistycznymi: ukraińską i rosyjską. Kwestia litewska pozostała formalnie nierozstrzygnięta do 1938 r., choć w sensie faktycznym ziemie zajęte przez Polskę w wyniku tzw. buntu Żeligowskiego zostały w 1922 r. bezpośrednio włączone do państwa polskiego i stan ten został utrzymany do $1939 \mathrm{r}$.

Spośród państw, które w wyniku rozstrzygnięć zapadłych po I wojnie światowej zdołały wybić się na niepodległość, w mniejszym stosunkowo stopniu uwagę polskich elit przykuwały Łotwa i Estonia. Nie znaczy to jednak, iż pozostawały zupełnie nieobecne. Świadectwem zainteresowania Rzeczypospolitej obiema późniejszymi republikami sowieckimi pozostawało podpisanie porozumienia o stworzeniu (17 marca 1922 r.) Związku Bałtyckiego, w skład którego - oprócz Polski i wymienionych państw - wchodziła również Finlandia. Niemniej świadomość znikomego znaczenia obu krajów jako czynnika 
demograficzno-gospodarczego z jednej strony, z drugiej zaś zawiązanie tzw. ententy bałtyckiej i skupienie uwagi Polaków na niebezpieczeństwie ze strony Rosji Sowieckiej i Republiki Weimarskiej sprawily, iż obecność Estonii i Łotwy została sprowadzona na margines rozważań o polskiej geopolityce. Wszystkie późniejsze republiki związkowe funkcjonowały wprawdzie jako elementy koncepcji intermarium, jednak wraz ze stabilizacją funkcjonowania wszystkich elementów międzymorskiej uktadanki w systemie wersalsko-waszyngtońskim realizacja tak ambitnego projektu skazana była na porażkę.

Jak się miało okazać, los Polski i państw bałtyckich został przesądzony już 22 sierpnia 1939 r. Na skutek zawarcia paktu Ribbentrop-Mołotow wszystkie te państwa utraciły de facto swój suwerenny byt, dzieląc los Ukrainy i Białorusi. Ustalony wówczas porządek nie stracił również na aktualności nawet po przejściu ZSRS do obozu aliantów. Utrwalenie osiągniętych w 1939 r. zdobyczy, a następnie poszerzenie strefy wpływów Kraju Rad stało się jednym z celów wojennych Moskwy, w konsekwencji zaaprobowanych przez państwa koalicji przy stole rokowań w Jałcie i w Poczdamie.

\section{Ukraina i Białoruś w powojennej refleksji polskiej emigracji}

Porządek zaprowadzony w 1945 r. sprawił jednak, iż sprawa Białorusi, Estonii, Litwy, Łotwy i Ukrainy przestała być wyłącznie kwestią przynależną myśli politycznej, a stała się tematem znacznie szerszym. Należy podkreślić, iż $\mathrm{w}$ rozważaniach geopolitycznych dominowała narracja narzucona przez obóz piłsudczykowski w trakcie II wojny światowej. To właśnie dawni adherenci Piłsudskiego - wykluczeni z systemu politycznego, jaki zawiązany został w kraju i na emigracji, a jednocześnie ponoszący polityczne konsekwencje przegranej kampanii polskiej 1939 r., okazali się środowiskiem, które wprowadziło najbardziej spójną, choć jednocześnie najambitniejszą i trudną w realizacji, wizję koegzystencji narodów żyjących w przestrzeni bałtycko-czarnomorsko-adriatyckiej. Niewątpliwie takie postacie jak Ignacy Matuszewski, Juliusz Łukasiewicz, Janusz Jędrzejewicz, Władysław Wielhorski czy Stefan Mękarski odwoływały się do dziedzictwa ideowego własnego obozu i rozwiązań wypracowanych w latach 1914-1939, przede wszystkim do konceptów prometejskich i federacyjnych.

Nowościami, które dawni sanatorowie zdołali wypracować i narzucić $\mathrm{w}$ debacie politycznej (ograniczonej wprawdzie do dyskusji w wewnątrzpolskim środowisku politycznym), były z jednej strony zasięg wizji, z drugiej zaś zdolność łączenia polskich celów politycznych z dokonaniami naukowymi klasyków geopolityki anglosaskiej, przede wszystkim sir Halforda Mackindera. 
Cechą charakterystyczną dla późniejszych prezentacji miejsca niektórych republik związkowych ZSRS był język komunikacji, którego brakowało w przedwojennych próbach przekonywania zagranicy do polskich pomysłów urządzenia przestrzeni środkowej i wschodniej Europy. Piłsudczycy zaczęli prezentować swe przemyślenia w sposób, który elity anglosaskie poznawały w trakcie wykładów swych wybitnych profesorów, prowadzących zajęcia na tak renomowanych uczelniach jak brytyjskie Oxford czy London School of Economics oraz amerykańskie Stanford czy Yale. Wychodząc skądinąd ze słusznej diagnozy, iż w świecie Zachodu to Amerykanie będą narodem, który będzie narzucał polityczny ton globalnym rozwiązaniom, zaczęli też przekazywać swe treści, odwołując się $\mathrm{z}$ jednej strony do analogii między zorganizowaniem przestrzeni środkowoeuropejskiej a funkcjonowaniem unii stanów w Ameryce Północnej, z drugiej zaś wskazując na konieczność osłabienia Związku Sowieckiego przy użyciu zmian terytorialno-geograficznych jako jednego $\mathrm{z}$ warunku osiągnięcia globalnych celów Waszyngtonu. Przede wszystkim Ukraina - z racji swej wielkości i liczby ludności - zajmowała w tychże koncepcjach miejsce naczelne, niemniej jednak nie zapominano o przestrzeniach, które w zamierzchłej historii składały się na Rzeczpospolitą Obojga Narodów.

W eksponowaniu wizji geopolitycznych, przyjmowanych zresztą w różnych wariacjach przez środowiska polityczne polskiego wychodźstwa, a także (po 1979 r.) przez opozycję w PRL, dominowały dwie, przenikające się zresztą, kategorie: 1) bezpieczeństwo i 2) wywodzone z argumentacji historycznej silne eksponowanie iunctim między pomyślnością narodów środkowoeuropejskich a zdolnością Rzeczypospolitej do moderowania przestrzeni między ówczesną Rosją a Niemcami.

Odnosząc się przede wszystkim do Litwinów i Ukraińców, wskazywano, iż właśnie ich egoistyczne pojmowanie interesów narodowych było (przed 1922 r.) czynnikiem niweczącym plany osłabienia imperializmu rosyjskiego. Równocześnie jednak nawiązanie współpracy z Ukraińcami i Litwinami, jak również z Łotyszami i Estończykami, uznawane było za podstawę wszelkich działań służących budowie systemu regionalnego bezpieczeństwa. Tak skonstruowana przestrzeń stanowić miała podstawę do rozszerzenia antymoskiewsko zorientowanej strefy o kolejne narody ciemiężone przez Rosję, przede wszystkim Gruzinów oraz Tatarów. Twórcy koncepcji wskazywali bardzo mocno na jeszcze inny aspekt. Polityczne scalenie obszarów Polski, Ukrainy, Białorusi, Litwy, Łotwy i Estonii otwierać miało też inne możliwości funkcjonowania w środowisku międzynarodowym. Każde z tych państw z osobna tracić miało przede wszystkim na postrzeganiu i traktowaniu go przez międzynarodowych uczestników gry jako małego, w najlepszym razie średniego, organizmu państwowego. Zdolność występowania jako związku scalającego ówcześnie (w końcu lat 40. XX w.) ponad $120 \mathrm{mln}$ ludzi 
i blisko $1 / 5$ przestrzeni kontynentu miała sprawić, iż byt taki miał być postrzegany jako ważny uczestnik działań politycznych w Europie Środkowej.

Choć fiasko realizacji zawężonych koncepcji geopolitycznych (w stylu konfederacji polsko-czechosłowackiej) wywarło decydujący wpływ na zarzucenie już w trakcie II wojny światowej pomysłów opartych o związki bilateralne, jednak dopiero ukształtowanie rzeczywistości jałtańsko-poczdamskiej zdecydowało o utrwaleniu w świadomości kreatorów idei nowego ładu środkowoeuropejskiego przekonania o konieczności opracowania uregulowań dotyczących obszaru zamieszkiwanego przez Ukraińców, Białorusinów, Litwinów, Łotyszy i Estończyków. Główną przesłanką dla postulowanych rozwiązań pozostawało bowiem uczynienie z tej przestrzeni efektywnego tygla narodów czynnie przeciwstawiającego się sowietyzacji, postrzeganej jako dążenie do unicestwienia politycznego i kulturowego państw przestrzeni bałtycko-czarnomorsko-adriatyckiej. Dlatego też - w odróżnieniu od programów ferowanych przez większość środowisk politycznych w okresie II Rzeczypospolitej - istotną rolę zaczęto przywiązywać do kwestii świadomości narodowej potencjalnych uczestników postulowanego aliansu.

Nie mogło dziwić, iż z racji wielkości i liczebności, a także skomplikowania relacji tak w okresie polskiej niepodległości, jak i w latach II wojny światowej, na pierwszy plan przez środowiska polskiej emigracji niepodległościowej wysuwana była kwestia koegzystencji Polaków z Ukraińcami. Poruszający tę kwestię bezpośrednio po II wojnie światowej bazowali przede wszystkim na analizie potencjału i znaczenia ludności ukraińskiej w dotychczasowych doświadczeniach historycznych państwa polskiego. Co charakterystyczne, dominowało przekonanie o potrzebie odrobienia wielowiekowego zaniedbania tego problemu w okresie I Rzeczypospolitej oraz wyrzeczenia się tego fragmentu dziedzictwa obu narodów, wynikającego z funkcjonowania w ramach struktur państwa carów czy monarchii austro-węgierskiej.

Przy kreowaniu wizji dotyczących możliwości efektywnej współpracy z Ukraińcami wyraźnie marginalizowane były zarówno kwestie wynikające z wzajemnych zadrażnień istniejących w okresie międzywojennym, jak i z udziału Polaków i Ukraińców w działaniach militarnych II wojny światowej. Niemal niedostrzegalna była kwestia ukraińskich mordów popełnionych na ludności polskiej, przede wszystkim na Wołyniu, jak również akcji odwetowych polskiego podziemia, a jeśli kwestia ta w ogóle była podnoszona, dominowało przekonanie, iż narodowe krzywdy winny zostać poświęcone w imię perspektywicznego wspóldziałania przeciwko wspólnemu zagrożeniu. Tym bardziej iż od połowy lat 40 . widoczne było $\mathrm{w}$ większości polskich środowisk politycznych przekonanie, iż od związku z Ukrainą powinny zostać zapoczątkowane działania prowadzące do realizacji koncepcji Międzymorza. 
Oprócz argumentacji historycznej dominowała teza, iż dla dokonywanej wewnątrz obszaru regulacji, a także dla działań integrujących przestrzeń międzymorza decydujące znaczenie będzie miała gospodarka. $\mathrm{Z}$ tejże przesłanki wynikało stopniowe odchodzenie od tradycyjnie polskiego postrzegania ziem na wschód od Zbrucza jako spichlerza Europy i przeciwstawienie mu gospodarczego obrazu Ukrainy widzianego przez pryzmat posiadanych przez nią zasobów naturalnych, głównie węgla kamiennego i rud metali. Za nie mniej ważne niż walory ekonomiczne uznawane było strategiczne położenie Ukrainy. Jej usytuowanie na pobrzeżu czarnomorskim powodowało, że mogła odgrywać rolę głównej zapory przed ewentualnym zagrożeniem ziem polskich nie tylko ze strony ZSRS, lecz również kulturowo obcych Europie krajów Kaukazu, Środkowego Wschodu oraz Turcji (niezależnie od tego, iż narody te były również postrzegane przez Polaków jako potencjalni sprzymierzeńcy przeciwko imperializmowi rosyjskiemu).

Wśród polskich analityków panować miała zasadnicza zgodność, iż wyemancypowanie się tych terenów spod wplywów ZSRS równałoby się utarcie znaczenia i przekreśleniu mocarstwowych ambicji Moskwy. Dlatego też właśnie o ziemie ukrainne miała się rozegrać główna batalia przesądzająca o zdolności Rosjan do panowania nad przestrzenią środkowoeuropejską, a utrata wpływu nad Ukrainą miała jakoby ostatecznie zepchnąć Rosję do roli państwa azjatyckiego. Jak zgodnie prognozowano, w przyszłości Ukraina skazana była albo na szerszy związek z Polską i narodami środkowej Europy, stając się jednocześnie ważną zaporą obronną tej części kontynentu wobec naporu ze wschodu, albo też na pogodzenie się z podporządkowaniem i ponownym popadnięciem w niewolę Rosji. Niezależnie od pewnej abstrakcyjności tego tematu w ówcześnie panujących warunkach geopolitycznych należy podkreślić, iż niektóre środowiska polskie postulowały uprzednie rozstrzygnięcie przez Ukraińców kwestii przynależności Lwowa (oczywiście w duchu zagwarantowania praw Polski do Wiernego Miasta) czy wręcz domagały się go.

Paradoksalnie więcej emocji w pierwszych latach powojennych wywoływała kwestia postrzegania Białorusinów jako ewentualnych partnerów politycznych. Stan ten wynikał najprawdopodobniej z doświadczeń wyniesionych z okresu II Rzeczypospolitej. Za wstrzemięźliwością wobec tej nacji przemawiać miała przejawiana przez nią inklinacja ku szeroko rozumianej rosyjskości. Pamiętano bowiem, iż w okresie międzywojennym to właśnie środowiska białoruskie wykazywały podatność na wpływy komunistyczne i nierzadko występowały w roli sowieckiego narzędzia czy wręcz agentury. Przekonanie to potęgowała świadomość strat poczynionych w substancji narodowej i mentalności Białorusinów w części wchłoniętej etapami do ZSRS, najpierw po traktacie ryskim, następnie po agresji sowieckiej 17 września 1939 r. Białorusini uznawani 
byli za nację, która w czasie dwudziestolecia i II wojny światowej uległa sowietyzacji w największym stopniu. Dlatego też w refleksji środowisk politycznych w stosunku do Białorusinów widoczne były dwa punkty widzenia. Pierwszy, w którym dominowało przekonanie o potrzebie korekty rozwiązań polityki narodowościowej wypracowanych w okresie II Rzeczypospolitej. Drugi, sprowadzający się do postulatu rezygnacji z ujmowania problemu Białorusinów jako elementu programu federacyjnego i przesunięcia akcentów w kierunku objęcia tej nacji rozwiązaniami prometejskimi.

\section{Polskie uchodźstwo powrześniowe wobec zagadnienia państw nadbaltyckich}

Tuż po zakończeniu II wojny światowej stosunkowo najwięcej kontrowersji w rozważaniach przedstawicieli polskich środowisk politycznych wywoływała kwestia postrzegania państw bałtyckich i dotyczących ich rozwiązań. Ze zrozumiałych względów centralne miejsce w tej przestrzeni zajmowała Litwa. Oczywiście w postrzeganiu Litwy dominował przekaz odwołujący się do argumentacji historycznej. Na pierwszy plan wysuwała się pamięć ścisłych związków będących konsekwencją decyzji powziętych przez przedstawicieli obu narodów w Krewie (1385), Horodle (1413) i Lublinie (1569) i zdaniem większości przedstawicieli elit politycznych nic nie stało na przeszkodzie, aby związki te zostały $w$ jakiejś formie zrewitalizowane.

Oczywiście zdawano sobie sprawę z czynników dezintegrujących i faktów zaistniałych w okresie II Rzeczypospolitej. Niewątpliwa była świadomość, że kwestią dzielącą obie strony była sprawa określenia stolicy państwa litewskiego. Przeciwstawienie racji historycznych rzeczywistości demograficznej traciło na znaczeniu wobec powziętych przez Wielką Trójkę decyzji o wykreśleniu granic i repatriacjach jako sposobie rozwiązania kwestiinarodowościowych. Niezależnie od sowieckiej socjotechniki wymierzonej w obecność Polaków w Wilnie kwestia przynależności miasta nad Wilią jako główny problem dzielący Polaków i Litwinów nie wydawała się ostatecznie rozwiązana. Mimo rozstrzygnięć jałtańsko-poczdamskich wyrzeczenie się przynależności Wilna, podobnie zresztą jak Lwowa, nie mieściło się w katalogu polskich celów politycznych nie tylko przedstawicieli części stronnictw, lecz również ludzi kultury czy członków organizacji społecznych i zawodowych.

Szczególnie stanowisko to widoczne było w poglądach osób, które po II wojnie światowej znalazły się na emigracji w Europie Zachodniej, przede wszystkim w Wielkiej Brytanii. Należy przy tym zauważyć, iż w większości była to społeczność, którą łączył nie tylko sentyment powodowany przywiązaniem 
do przedwojennego miejsca urodzenia czy też zamieszkiwania. Na wspólnotę poglądów niebagatelny wplyw miały ich wojenne losy naznaczone przez wywózki, deportacje i - w ich mniemaniu - cudowne ocalenie stanowiące pokłosie umowy Sikorski-Majski.

Immanentną częścią myślenia o statusie niezmiennie polskich miast w tej części wychodźstwa polskiego pozostawała bezgraniczna wiara w rządową interpretację pierwszego punktu układu zawartego z Sowietami 30 lipca $1941 \mathrm{r}$. W myśl tej interpretacji passus o utracie mocy porozumień dotyczących statusu terytorialnego ziem rozgraniczonych mocą paktu Ribbentrop-Mołotow oznaczać miał automatyczny powrót do granicy ryskiej. Szereg czołowych postaci polskiego życia politycznego i kulturalnego na uchodźstwie, które zawdzięczały uwolnienie tzw. amnestii, wynikającej z zastosowania układu, nie wyobrażało sobie, iż publiczne enuncjacje premiera i Naczelnego Wodza w jednej osobie zupełnie inaczej były interpretowane przez stronę sowiecką i że to władze ZSRS w ostatecznym rozrachunku narzuciły aliantom korzystne dla siebie rozwiązanie problemu polskich kresów. Przekonanie to przekładało się na irracjonalnie uargumentowaną postawę o konieczności podejmowania działań, wymuszających na aliantach dotrzymanie obietnic rzekomo złożonych polskiemu premierowi. Zgodnie z tym z natury intencjonalnym sposobem postrzegania politycznych realiów Ukraina i Litwa, a przynajmniej ich znaczące części, winny stać się nierozerwalnym elementem Rzeczypospolitej.

Niezależnie jednak od emocjonalnego tonu, jaki wybrzmiewał przy okazji podejścia do ziem w przeszłości silnie związanych z Polską, państwa bałtyckie, podobnie zresztą jak Ukraina, pozostawały jednym z głównych elementów rozważań na temat powojennego bezpieczeństwa. W tej materii jednak intelektualiści, a w szczególności osoby utożsamiające się z głównymi nurtami polskiej myśli politycznej, znacznie różnili się w swych zapatrywaniach. Zasadnicza różnica sprowadzała się do kwestii zasadności traktowania obszaru między Rosją a Niemcami, czy szerzej przestrzeni intermarium między morzami Bałtyckim, Czarnym i Adriatyckim, jako unitarnej czy też zróżnicowanej przestrzeni.

W kwestii stosunku państw bałtyckich do przestrzeni publicznej przebijały się trzy zasadnicze ujęcia: maksymalistyczne, umiarkowane i tzw. realistyczne. Ujęcie maksymalistyczne, charakterystyczne dla przemyśleń polityków piłsudczykowskich i reprezentantów polskiego socjalizmu, nawiązywało wprost do idei jagiellońskiej i myślenia charakterystycznego dla twórców idei federacyjnej. Zasadniczym celem propagatorów tej koncepcji pozostawały brak akceptacji dla rozstrzygnięć podyktowanych w Jałcie i Poczdamie oraz zapewnienie bezpieczeństwa akwenowi baltyckiemu. Podstawowym problemem wysuwanym na pierwszy plan był sprzeciw wobec trwałej utraty suwerenności przez Litwę, Łotwę i Estonię oraz wobec rozwiązania kwestii Prus Wschodnich. 
W diagnozie przedstawicieli tych środowisk, abstrahując od kwestii niepodległości państw bałtyckich, uznawanej za jeden z priorytetów wymagających natychmiastowej korekty, usadowienie się Rosji na terenach okalających Królewiec uznane zostało za czynnik potęgujący zagrożenie międzynarodowe, nie zaś stabilizujący lad regionalny. Zdaniem takich przedstawicieli nurtu piłsudczykowskiego jak Janusz Jędrzejewicz czy Juliusz Łukasiewicz, czy socjalistów: Adama Ciołkosza i Tomasza Arciszewskiego kwestia tegoż fragmentu terytorium pokonanej III Rzeszy winna zostać rozwiązana przez podział pomiędzy Polskę a Litwę. W sytuacji, gdy Litwa została wchłonięta przez Związek Sowiecki, obowiązkiem Polaków miało być upominanie się o korzystne dla niej rozwiązania, prowadzące nie tylko do zabezpieczenia interesów polskich i litewskich, ale wpływające na bezpieczeństwo regionalne, przede wszystkim swobodę żeglugi i dostęp do portów w Kłajpedzie, Rydze, Parnawie i Tallinie.

Niemniej takie postrzeganie tej części Europy Środkowo-Wschodniej było uwarunkowane podejściem do celu strategicznego, który winien zostać osiągnięty, jeśli nie w wyniku II, to na skutek III wojny światowej. Co do konieczności jej wybuchu w środowiskach tych panowała zasadnicza zgodność. Jak wskazywali analitycy socjalistyczni i piłsudczykowscy, ani przez Polaków, ani przez aliantów nie zostały osiągnięte cele, z którymi narody sprzymierzone przystępowały do działań wojennych. W wypadku sojuszników zachodnich cel ten został zdefiniowany jako uzyskanie określonego poziomu bezpieczeństwa zbiorowego, natomiast $\mathrm{w}$ wypadku Polski było to osiągnięcie minimum bezpieczeństwa regionalnego. Pod pojęciem tym kryła się intencja wyrugowania z przestrzeni środkowoeuropejskiej wpływów rosyjskich i niemieckich. Tak więc sytuacja, w której część państw regionu (w tym Litwa, Łotwa i Estonia) straciła swą podmiotowość i została wchłonięta przez Związek Sowiecki, a w kolejnej części wpływy niemieckie zostały zastąpione sowieckimi, pozostawała z założenia nieakceptowalna.

Propagatorzy tegoż spojrzenia stawiali jednoznacznie znak równości pomiędzy oddaniem państw bałtyckich Rosji i objęciem protektoratem moskiewskim krajów środkowej Europy a osłabieniem Zachodu. Ponadto, z punktu widzenia tychże środowisk, program federacyjny (niezależnie od jego znacznego zmodyfikowania w stosunku do pierwotnego wariantu z początków niepodległości czy koncepcji Trzeciej Europy z przedednia II wojny światowej) winien zostać uzupełniony strategicznym sojuszem $\mathrm{z}$ demokracjami zachodnimi. Te z kolei musiały zostać przekonane do wizji federacji, obejmującej przestrzeń bałtycko-adriatycko-czarnomorską. Choć poszczególni przedstawiciele środowisk piłsudczykowskich i socjalistycznych różnili się między sobą podejściem do detali, takich jak zasięg projektowanej federacji, liczba jej uczestników, skala 
spoistości przyszłego związku, to fakt konieczności włączenia do projektowanego związku Litwy, Estonii, Łotwy, Białorusi i Ukrainy miał nie podlegać dyskusji.

Podejście umiarkowane w stosunku do krajów bałtyckich cechowało przedstawicieli środowisk narodowych i chrześcijańskich demokratów spod znaku Stronnictwa Pracy. W wypadku tych ostatnich trudno jednak mówić o wypracowaniu szczególnie oryginalnych rozwiązań, a raczej o ogólnej akceptacji wizji wypracowanych w okresie wojny przez narodowców. Ci, szczególnie w pierwszych latach po zakończeniu II wojny światowej, w minimalnym stopniu zweryfikowali założenia wypracowane w jej trakcie przez Mariana Seydę, jeszcze w czasach, gdy sprawował on funkcję ministra bez teki w rządzie generała Władysława Sikorskiego. Według reprezentantów tegoż nurtu polskiej myśli politycznej postulowany przez środowiska lewicy (za takie uznawana była również sanacja) obraz szerokiej federacji pozostawał z gruntu niewykonalny, przede wszystkim z powodu skali przedsięwzięcia. Dlatego też narodowcy proponowali rozbicie realizacji programu unifikacji obszaru przynajmniej na dwa elementy, to jest związek północny stworzony przez państwa skandynawskie: Danię, Szwecję, Norwegię, Finlandię oraz dwa kraje baltyckie: Estonię i Łotwę, oraz związek południowy, w którego skład miały wejść Litwa, Polska, Czechosłowacja, Węgry, Rumunia, Jugosławia, Albania, Grecja, Bułgaria i Turcja.

Mimo rozstrzygnięć osiągniętych w trakcie konferencji w Jałcie i Poczdamie reprezentanci prawicy nie zdobyli się ani na szerszą aktualizację wypracowanych przez siebie rozwiązań, ani też na odparcie krytyki płynącej pod adresem przedstawionych propozycji. A skupiała się ona przede wszystkim na podejściu do obszaru najbliższego sąsiedztwa Polski. W koncepcji tej zwracało uwagę całkowite pominięcie ziem ukraińskich i białoruskich, co przeciwnicy ruchu narodowego jednoznacznie interpretowali jako wyraz hołdowania rusofilstwu i panslawistycznym mrzonkom. Wprawdzie narodowcy zyskiwali w tej kwestii dodatkowy argument, w myśl którego poddane tzw. repatriacji kresy wschodnie pozostawały nie do utrzymania przede wszystkim z powodu pozbawienia ich polskiego pierwiastka narodowego, niemniej jednak z rzadka był on używany w politycznej retoryce obozu. Podstawowy zarzut dotyczył również koncepcyjnego rozerwania ziem, stanowiących w interpretacji politycznych konkurentów spójną przestrzeń wyznaczoną granicami dawnego Wielkiego Księstwa Litewskiego. Narodowcy nie potrafili dostatecznie wyjaśnić nie tylko swym oponentom, lecz również adresatom swych projektów, dlaczego zdecydowali się postulować rozwiązanie skutkujące zerwaniem naturalnej łączności między Litwą, Łotwą i Estonią.

Mało tego, nie potrafili ustosunkować się również do podnoszonych wątpliwości z powodu niewłaściwego podejścia do kwestii bezpieczeństwa Bałtyku i cichego przyzwolenia na obecność Rosji w Prusach Wschodnich, 
i - poprzez usytuowanie Łotwy i Estonii w kręgu państw skandynawskich, co de facto miało się równać pozostawieniu tychże republik na łasce Związku Sowieckiego - uczynienia wyłomu w bałtyckim systemie bezpieczeństwa. Podobnie zresztą, jak do - określanego jako polityczny absurd - pomysłu scalenia przestrzeni od Litwy po Turcję i Albanię. W kwestii Litwy, przynajmniej do końca lat 40., obowiązywał w środowisku narodowym pogląd narzucony w okresie wojny przez Romana Rybarskiego o niezdolności tego państwa do samodzielnej egzystencji i konieczności objęcia go w przyszłości protektoratem polskim. Po konferencji w Jałcie narracja dotycząca bezpieczeństwa przestrzeni okołobałtyckiej została uzupełniona tezą (która może w późniejszych latach była mniej eksponowana, ale jednak pozostawała obecna w wypowiedziach przedstawicieli środowisk polskiej prawicy) o potrzebie akceptacji przyłączenia Ukrainy i Białorusi do ZSRS. Wchłonięcie obu tych krajów do Związku Sowieckiego poprzez zbliżenie Rosji do Niemiec będzie miało korzystny wpływ na bezpieczeństwo Rzeczypospolitej.

Trzecią, w początkowym okresie stosunkowo najmniej liczną, jednak wraz ze stabilizowaniem się systemu jałtańsko-poczdamskiego zyskującą na znaczeniu, pozostawała grupa realistów. $Z$ racji swych poglądów przez większość przedstawicieli wojennego wychodźstwa i przedstawicieli tradycyjnych nurtów politycznych traktowana była ona jako ekspozytura czy wręcz piąta kolumna reżimu warszawskiego. Grupa ta stała na stanowisku konieczności bezwzględnego respektowania postanowień jałtańskich i potrzeby stabilizacji kształtu terytorialnego Polski. Zdaniem przedstawicieli tegoż środowiska należało wyciągnąć wnioski z polityki rządów przedwrześniowych, cechujących się ruso(sowieto) fobią i uleganiem pseudomocarstwowym mrzonkom. Ta ostatnia formuła odnosiła się do twierdzeń reprezentantów innych nurtów, głoszących konieczność odzyskania Polski w kształcie przynajmniej nieuszczuplonym oraz obstających przy restytucji granic wschodnich, określonych traktatem ryskim.

W kontrze do tychże środowisk realiści wyrażali aprobatę dla pozbycia się obciążenia Rzeczypospolitej, jakim miała być przynależność licznych mniejszości narodowych. Ponadto Ukraińcy i Białorusini, a także Litwini, Łotysze i Estończycy, mający trudności z akceptacją niezdolności prowadzenia samodzielnej polityki zagranicznej i oparcia o Polskę, mieli - ich zdaniem - lepiej odnaleźć się $\mathrm{w}$ formule przynależności do państwa związkowego, jakim miał rzekomo pozostawać ZSRS.

Wysuwając na pierwszy plan argumenty ekonomiczne, przekonywano, iż dla Rzeczypospolitej wyrzeczenie się przynależności do niej Wilna i Lwowa oraz ułożenie relacji z Ukraińską, Białoruską, Litewską, Łotewską i Estońską Socjalistycznymi Republikami Sowieckimi było nieodzowne do akceptacji mocarstw dla włączenia w granice Rzeczypospolitej tzw. Ziem Odzyskanych. 
Choć tuż po zakończeniu II wojny światowej tego typu zapatrywania wydawały się mieć znikome szanse oddziaływania, jednak wraz z intensyfikacją tzw. akcji repatriacyjnej przekaz o nieodwracalności utraty podmiotowości przez Litwę, Łotwę i Estonię, a także o trwałości rzekomego zjednoczenia Ukrainy i Białorusi oraz o entuzjazmie Ukraińców i Białorusinów wobec egzystowania w formule sowieckich republik stawał się słyszalny.

\section{Polska emigracja po II wojnie światowej wobec problemu sowietyzacji Europy Wschodniej}

W narracji, która zaczęła się pojawiać w końcu lat 40. i była charakterystyczna dla początków kolejnej dekady w odniesieniu do całego obszaru Europy Środkowej, dominował przekaz dotyczący sowietyzacji przestrzeni objętej wpływami Związku Sowieckiego. Co charakterystyczne, przedstawiciele rozmaitych środowisk politycznych wskazywali na postępujący proces z jednej strony upodabniania przestrzeni nadbaltyckiej i środkowoeuropejskiej do systemu sowieckiego, z drugiej zaś na intensyfikację izolacji od świata Zachodu. Zasadniczą część wypowiedzi przedstawicieli rozmaitych opcji politycznych zajmował obraz rubieży dawnej Polski, poddanej unifikacji do systemu komunistycznego, w zasadzie jednorodny zarówno w stosunku do Rzeczypospolitej, jak i krajów z jej najbliższego otoczenia.

W przekonaniu reprezentantów różnych nurtów politycznych celem ZSRS pozostawało zbudowanie i utrzymanie strefy wpływów, pozwalających włodarzom Kremla na stworzenie jednorodnej strefy zdolnej odgrywać rolę gospodarczego, demograficznego i politycznego zasobu - szczególnie pożytecznego choćby z racji członkostwa krajów satelickich w organizacjach międzynarodowych, przede wszystkim Organizacji Narodów Zjednoczonych. Dostrzegano wprawdzie, iż zakres sowietyzacji bywał nieco odmienny i zależny od faktu, czy dany obszar pozostawał jedynie w orbicie wpływów Kraju Rad, czy też wchodził w skład ZSRS jako republika związkowa. Niemniej jednak dominował przekaz, że jeśli nawet Polska nie podzieliła losu Ukrainy, Białorusi, Litwy, Łotwy i Estonii, to i tak stan, w którym znajdowało się ówcześnie społeczeństwo polskie, stanowi etap przygotowawczy do wprowadzenia na ziemiach określonych jako Polska Rzeczpospolita Ludowa pełnego systemu sowieckiego. Tak bowiem odbierano płynący z Moskwy przekaz, iż narody, które w wyniku porozumień jałtańsko-poczdamskich znalazły się w orbicie wpływów Kremla, ujście dla swych narodowych aspiracji mogły znaleźć jedynie w ZSRS, natomiast ich status ekonomiczny, terytorialny czy też zamożność społeczeństwa zależne były wprost od dyrektyw wypracowanych przez kompartię i od woli politycznego protektora. 
Według obserwacji czynionych z pozycji Londynu, Paryża czy Nowego Jorku pierwszą ofiarą akcji sowietyzacyjnej padły narody bałtyckie. Było to konsekwencją założeń geopolitycznych o otwarciu drogi ku akwenom północnym, niezbędnym ZSRS do utrzymania kluczowej pozycji wyjściowej na Bałtyku oraz w akwenach okalających pobrzeże północne. Dlatego też Litwa, Łotwa i Estonia miały zostać pozbawione jakichkolwiek możliwości oporu wobec odgórnie narzuconej sowietyzacji i znaleźć się zamknięte na głucho w złowrogich kleszczach sowieckiego raju.

Nieco więcej kłopotów dostarczała środowiskom polskim poza granicami kraju kwestia ustosunkowania się do problemu ukraińskiego. Szczególnie sprawa ta pozostawała widoczna w opiniach adherentów Józefa Piłsudskiego oraz przedstawicieli lewicy. Jakkolwiek widoczna była różnica w rozkładzie akcentów, reprezentantom tych nurtów z jednej strony trudno było przejść do porządku dziennego nad faktami zaistniałymi w okresie dwudziestolecia (przede wszystkim nad aktywnością Organizacji Ukraińskich Nacjonalistów i zamachami na Tadeusza Hołówkę i Bronisława Pierackiego) i w latach II wojny światowej (nad wymierzoną w Polaków kolaboracją środowisk ukraińskich z nazistami czy wydarzeniami na Wołyniu), z drugiej zaś zasadnicza rewizja poglądów wymagałaby całkowitego wyrzeczenia się (a przynajmniej daleko idących modyfikacji) idei federacyjnych i prometejskich, stanowiących - po 1944 r. - element konstytutywny myśli politycznej obu środowisk.

Stąd też wynikał dominujący w obu środowiskach głos o braku możliwości zaakceptowania porozumień jałtańskich, choćby z tego powodu, iż równałoby się to nie tylko utracie połowy przedwrześniowego terytorium, lecz również zgodzie na oddanie pod obcą jurysdykcję ponad trzech milionów własnych obywateli. Co za tym idzie, w publicystyce czołowych przedstawicieli obu nurtów widoczne były próby usprawiedliwiania antypolskich poczynań ukraińskich. Co jednak charakterystyczne, kreujący tego typu narrację mieli z nią wyraźny kłopot polegający na braku rozstrzygnięć, czy aktywność ludności ukraińskiej przedstawić jako wynik działań Niemców, czy też piątej kolumny bolszewickiej.

Niemniej jednak w obu środowiskach panowała zasadnicza zgodność, jeśli chodziło o diagnozę relacji polsko-ukraińskich i konkluzje, iż II wojna światowa z jednej strony przyczyniła się do rozbudzenia ukraińskich dążeń narodowościowych i starań o odbudowę własnej państwowości, z drugiej zaś do utrwalenia stanowisk antypolskich. Wskazywano przy tej okazji, że ówczesny moment - spowodowany z jednej strony rozczarowaniem Ukraińców co do efektów budowy własnego państwa w oparciu o III Rzeszę, z drugiej zaś sowietyzacją i faktyczną likwidacją ukraińskiej myśli narodowej na terenach włączonych do Kraju Rad - sprzyjać miał zacieśnieniu związków z Polską. Zarówno w ukraińskim, jak i w polskim interesie leżała obrona żywiołu ukraińskiego przed totalnym 
zrusyfikowaniem, zwłaszcza że (jak pokazało uwięzienie hierarchów cerkwi greckokatolickiej we Lwowie) Ukraińcy mieli w tym samym stopniu co Polacy doświadczać dobrodziejstw sowietyzacji. Szczególnie wśród sukcesorów piłsudczykowskiej myśli politycznej dobitnie wybrzmiewała teza, iż w przyszłych zmaganiach z Rosją nie można było lekceważyć potencjału demograficzno-gospodarczego Ukrainy, a właśnie antysowiecko nastawione elity ukraińskie wydawały się podatne na przekonanie do porozumienia politycznego, a w dalszej przyszłości do wdrożenia idei prometejskiej i federacyjnej.

Dla porząalku należy odnotować głosy płynące z drugiej strony politycznej barykady, tj. bezpośrednio z obozu narodowego. Reprezentatywne stanowisko w tej mierze prezentował Jędrzej Giertych, stojąc konsekwentnie na stanowisku nakreślonym u progu XX stulecia przez Romana Dmowskiego. Według czołowego reprezentanta nurtu narodowego nie można było Ukraińców traktować jako odrębnego narodu, a co najwyżej jako odmienny szczep rosyjski, skupiony w określonej geograficznie przestrzeni.

Charakterystycznym elementem postrzegania przestrzeni okalającej wschodnie otoczenie pojałtańskiej Polski było porzucenie w początkach lat 50. zindywidualizowanego spojrzenia na kraje sąsiadujące z Polską. Fakt ten nie był bynajmniej efektem potraktowania Białorusi, Ukrainy oraz Litwy, Łotwy i Estonii w kategoriach zsowietyzowanej przestrzeni, której trudno było przywrócić podmiotowość. Stan ten pozostawał pośrednią pochodną rozstrzygnięć w wojnie koreańskiej, które przede wszystkim uświadomiły polskim elitom politycznym brak uzasadnienia dla - noszącej znamiona myślenia życzeniowego - tezy o nieosiągnięciu celów II wojny światowej i o rychłym wybuchu kolejnego konfliktu. Stopniowo do polskich kręgów politycznych przebijała się myśl zarówno o płonnych nadziejach na III wojnę światową oraz na przeobrażenia w części kontynentu stanowiącej domenę wplywów sowieckich, jak i o utrwalaniu się stanu zimnej wojny.

\section{Koncepcja integracji Europy Środkowo-Wschodniej}

Fakt ten wpływał bezpośrednio na zmianę postrzegania Ukrainy, Białorusi oraz państw bałtyckich. Dotychczasowe odniesienie się do tych krajów jako bariery okalającej Rzeczpospolitą ustępowało powoli na rzecz tezy o traktowaniu tychże krajów i narodów jako elementu szerszego, ponadnarodowego związku regionalnego. Wymownym świadectwem tego stanu rzeczy pozostawał postulat, by oferty współdziałania na rzecz odrzucenia sowietyzacji środkowej Europy i wyzwolenia się spod wpływów Moskwy nie ograniczać wyłącznie do Białorusinów, Estończyków, Litwinów, Łotyszy i Ukraińców, ale skierować ją 
pod adresem wszystkich nacji zamieszkujących przestrzeń tak zwanego międzymorza, nawet tych, co do których w początkach lat 50. zagrożenie imperializmem sowieckim wydawało się czymś odległym. Stąd też założenie, by ofertę międzynarodowego współdziałania wolnych narodów przedstawić możliwie szeroko i by (oprócz wymienionych) skierować ją również do Albańczyków, Bułgarów, Chorwatów, Czechów, Greków, Rumunów, Serbów, Słowaków, Słoweńców i Węgrów.

Praktycznym wyrazem wdrażania tej idei pozostawać miało tworzenie w różnych punktach świata tzw. Środkowoeuropejskich Klubów Federalnych, skupiających w pierwszej kolejności przedstawicieli narodów objętych bezpośrednią zależnością od ZSRS. Kluby te miały pozostawać otwarte na współdziałanie ze środowiskami reprezentującymi pozostałe państwa obszaru, co stanowić miało punkt wyjścia do podjęcia szerokiej dyskusji na temat możliwości prowadzenia wspólnej polityki regionalnej.

Z czasem urzeczywistnienie postulowanej koncepcji federacyjnej uznane zostało przez przedstawicieli polskich elit za jedyny sposób wydobycia się państw Europy Środkowo-Wschodniej z niewoli sowieckiej, niezależnie od tego, czy wchodzily one w skład Kraju Rad jako republiki związkowe, czy też znajdowały się jedynie w strefie wpływów Moskwy. Wraz z postępującym podporządkowaniem podbitych państw i narodów dyrektywom plynącym z kierownictwa partyjno-państwowego ZSRS projektowany Związek Narodów zaczynał być postrzegany jako zasadnicza alternatywa dla modelu sowieckiego totalitaryzmu. Podstawowym warunkiem pozostawała jednak redefinicja i konsolidacja dążeń politycznych tzw. narodów ujarzmionych i aprobata dla zjednoczenia obszarów międzymorza adriatycko-bałtycko-czarnomorskiego.

Warunkiem zasadniczym, bez którego realizacji nie wyobrażano sobie osiągnięcia tak ambitnie zakrojonego celu, było pozyskanie akceptacji świata zachodniego. Stąd też wynikało częste odwoływanie się do wartości zrozumiałych dla społeczeństw tzw. wolnego świata, tj. poszanowania prawa międzynarodowego i obrony elementarnych praw człowieka. Mimo nieskrywanego antysowieckiego nastawienia przedstawicieli elit forsujących powyższe rozwiązania wśród większości reprezentantów polskich nurtów politycznych dominowało przekonanie, iż sam rozwój imperializmu sowieckiego był czynnikiem sprzyjającym procesowi integracji Ukraińców, Białorusinów, Litwinów, Łotyszy i Estończyków z Polakami, a także wyzwalaniu się spod sowieckiej dominacji. Za przekonaniem tym szła zresztą głoszona otwarcie teza, iż wzmocnienie ZSRS przez wchłanianie kolejnych narodów do sowieckiej wspólnoty zwiększało liczbę potencjalnych partnerów Polski, gotowych przyłączyć się do ruchu prometejskiego. Problem Ukrainy i - w mniejszym stopniu - Litwy pojawiał się jednak w kontekście potencjalnych zagrożeń wpływających na spoistość 
projektowanego związku. Spornymi kwestiami pozostawały niezmiennie przynależność Wilna i Lwowa oraz szeroko rozumianych Kresów, a także aspiracje ukraińskie odnośnie do przynależności Małopolski Wschodniej i Rusi Zakarpackiej. Jednocześnie padały jednak ze strony środowisk polskich łagodzące stwierdzenia o strategicznym znaczeniu odsunięcia Związku Sowieckiego od linii Karpat i podporządkowaniu temu celowi egoizmów narodowych, a także o gotowości Polaków do rozstrzygnięcia tego problemu w przyszłości.

\section{Przeszłość i przyszłość jako argumenty za integracją Europy Wschodniej}

Równolegle polskie środowiska polityczne i intelektualne starały się o wypracowanie alternatywnej argumentacji przemawiającej za zacieśnieniem więzów Polaków z Ukraińcami, Białorusinami, Litwinami, Łotyszami i Estończykami. Jednym z takich przykładów jest polityczny historyzm. Kierunek ten został wypracowany przez światowej sławy mediewistę Oskara Haleckiego, a kontynuowany przez historyków związanych z Polskim Ruchem Wolnościowym Niepodległość i Demokracja (PRW NiD), często - z racji reprezentacji pokoleniowej i zapożyczeń ideowych, ale najzupełniej niesłusznie - nazywany formacją postpiłsudczykowską. W dyskusji nad powiązaniami Polski z krainami ościennymi i przestrzenią bałtycką historycy ci powrócili w swych badaniach do czasów koegzystencji Korony i Wielkiego Księstwa Litewskiego, a tym samym do stworzenia podwalin idei jagiellońskiej jako alternatywy zarówno dla maksymalistycznych w swym ujęciu programów federacyjnych, jaki i ruchów prometejskich.

Największą zasługą Oskara Haleckiego, któremu zresztą przypisuje się stworzenie pojęcia Europa Środkowo-Wschodnia, było przedstawienie spójnej historiozoficznej wizji przestrzeni środkowoeuropejskiej jako obszaru, który oddzielat Święte Cesarstwo Rzymskie, lub też narody teutońskie i romańskie z jednej strony, od euroazjatyckiej Rosji, tj. wschodnich Stowian, którzy w pewnych okresach dziejów znaleźli się poza wspólnotą europejska, z drugiej strony. Wychodząc $\mathrm{z}$ tego argumentu, Halecki starał się przedstawić specyfikę obszaru zamieszkanego przez Polaków, Ukraińców, Białorusinów, Litwinów, Łotyszy i Estończyków jako regionu, który w swych dziejach i procesie rozwoju podlegał zasadniczo odmiennym uwarunkowaniom i który zdołał wytworzyć odmienny typ państwowości i poczucia przynależności narodowej.

W toczonej ówcześnie dyskusji najważniejsze pozostawało stwierdzenie stanowiące głos w kwestii federalizmu wskazujący na uniwersalność i ponadczasowość federacji Rzeczypospolitej z Wielskim Księstwem Litewskim, 
przeciwstawiający jej federalizm sowiecki, nie mający nic wspólnego z ideą zacieśniania więzów między narodami środkowoeuropejskimi. Mało tego, to właśnie Oskar Halecki pozostawał rzecznikiem tezy, iż federacja, w której w zgodnej koegzystencji funkcjonowali Polacy, Ukraińcy, Białorusini, Litwini, Łotysze i Estończycy (podobnie zresztą jak skupiona wokół Dunaju przestrzeń byłej monarchii habsburskiej), mogła stanowić dla Europy Zachodniej modelowy przykład funkcjonowania związku państwowego.

Kontynuatorami tez głoszonych przez Haleckiego pozostawali dwaj historycy związani z PRW NiD, Piotr Stefan Wandycz i Marian Kamil Dziewanowski. Obaj zasłynęli próbami przełożenia uwarunkowań historycznych na język pragmatyki politycznej. W myśl ich wskazań związku państw Europy Środkowo-Wschodniej nie można było traktować w kategoriach mechanicznego rozwiązania problemu, ale jako podbudowę ideologiczną pozwalającą na przeciwstawienie się totalitaryzmowi. Według ich twierdzeń o powodzeniu ewentualnej federacji decydować miała wola narodów, a nie siła mocarstwa mierzona ilością dywizji i potencjału gospodarczego. Jako warunki niezbędne do stworzenia efektywnego organizmu związkowego określone zostały zbliżone interesy, struktura i położenie geograficzne. Podstawową kontrowersję generował jednak zakres projektowanej Unii. O ile Piotr Stefan Wandycz ograniczał ten problem albo do urzeczywistnienia idei jagiellońskiej (rozumianej jako stworzenie związku z udziałem narodów tworzących Rzeczpospolitą Obojga Narodów), albo do restytucji projektu konfederacji polsko-czechosłowackiej, o tyle Marian Kamil Dziewanowski formułował pogląd o konieczności zorganizowania możliwie szerokiego spektrum państw i narodów i oparcia idei federacji na morzach Adriatyckim, Bałtyckim, Czarnym i Egejskim. W obu jednak wypadkach konieczność uwzględnienia w projektowanej federacji udziału Polaków, Ukraińców, Białorusinów, Litwinów, Łotyszy i Estończyków pozostawała niemal bezsporna.

Pojawienie się argumentacji odwołującej się do czasów nowożytnych nie oznaczało bynajmniej przeniesienia punktu ciężkości w stanowisku zajmowanym przez polskich intelektualistów w sprawie zacieśnienia związków z narodami z najbliższego otoczenia Polski ze sfery politycznej na historyczno-symboliczną. Argumentacja historyczna nie zastępowała realnego, jak się miało wydawać, oglądu sytuacji i prognoz, które jakkolwiek ferowane były w krótkiej perspektywie, sprawdzily się na początku lat 90. XX w. Przede wszystkim wgląd w postępujący proces sowietyzacji państw bałtyckich oraz Białorusi i Ukrainy wskazywal, iż podstawowym instrumentem podporządkowania, użytym przez władze sowieckie, pozostawał terror. Obserwacja ta upoważniała $\mathrm{z}$ kolei do wysunięcia tezy o nietrwałości tworu opartego wyłącznie na aparacie przemocy. 
Wskazując na potencjał demograficzny, mówiono o zbyt wysokich kosztach ekonomicznych utrzymania republik sowieckich, wykreowanych, względnie poszerzonych, w wyniku przeobrażeń jałtańskich. Dodatkowym czynnikiem destabilizującym ZSRS miały być rozbudzone w okresie dwudziestolecia poczucie niezależności, patriotyzm i silne przywiązanie do tradycji państwowej. Ujawnienie skłonności do oporu przed rusyfikacją przez ludność zajmującą przestrzeń okalającą II Rzeczpospolitą miało pozostawać jedynie kwestią czasu. $\mathrm{Z}$ drugiej strony podkreślano jednak, iż podstawowe znaczenie w wypadku skutecznego oporu przeciwko sowietyzacji regionu nadbaltyckiego i terenów na wschód od Bugu będzie miała zdolność skupienia potencjału przy jednoczesnych gwarancjach zachowania odrębności przez każdy z narodów zamieszkujących środkową część kontynentu. Równocześnie problem związku Polaków z Ukraińcami, Białorusinami i reprezentantami narodów bałtyckich starano się przedstawić w jak najbardziej atrakcyjnej dla Zachodu formule antysowieckości, podkreślając potrzebę zanegowania cywilizacyjnych i społeczno-politycznych zmian narzuconych przez sowieckiego okupanta.

Stąd też wynikało szczególne zwrócenie uwagi na problem związków zachodzących między ustrojem gospodarczym a wolnością osobistą obywateli. $\mathrm{W}$ tej kwestii starano się uwypuklić problem dotykający nie tylko Polaków, Ukraińców, Białorusinów, Litwinów, Łotyszy i Estończyków, lecz również innych przedstawicieli narodów zdominowanych przez ZSRS. Stan ten wynikał z diagnozy, w myśl której bez zachodniego wsparcia udzielonego Europie Środkowo-Wschodniej na wzór planu Marshalla niemożliwe będzie otrząśnięcie się z sowieckich naleciałości i zbudowanie struktur gospodarczych pozwalających na zaspokojenie potrzeb państw, podjęcie normalnych kontaktów ekonomicznych z tzw. wolnym światem i umożliwienie obywatelom nieskrępowanego rozwoju własnej przedsiębiorczości. Ta z kolei niezbędna była do prawidłowego prowadzenia wspólnej polityki zagranicznej, zapewnienia bezpieczeństwa wszystkim uczestnikom potencjalnej federacji (utrzymania armii narodowych, a w dalszej perspektywie skonfederowanych sił zbrojnych) i prowadzenia nieskrępowanej współpracy naukowo-kulturalnej.

Co charakterystyczne, szczególnie w okresie kryzysu berlińskiego zdarzały się momenty, w których punkt ciężkości retoryki w kwestii organizacji przestrzeni zamieszkanej przez Polaków, Ukraińców, Białorusinów, Litwinów, Łotyszy i Estończyków przesuwał się w kierunku uświadomienia Zachodowi, iż współpraca narodów środkowoeuropejskich miała również na celu położenie tamy ekspansjonizmowi germańskiemu. Mało tego, dopuszczano również możliwość harmonijnej koegzystencji z narodem rosyjskim. Warunkiem niezbędnym ku temu pozostawało jednak wyrzeczenie się przez Rosjan zarówno imperialnych dążeń (tych ukierunkowanych kulturowo i skierowanych głównie 
przeciwko Ukraińcom i Białorusinom, a w dalszej mierze Polakom, i tych geopolitycznych, wymierzonych w suwerenność Estonii, Litwy i Łotwy), jak i komunizmu. Niezależnie od tego, iż większość polskich uczestników debaty politycznej za zasadniczy warunek unicestwienia imperium sowieckiego i odzyskanie wolności przez Polskę i pięć najbliższych jej republik sowieckich uznawała presję bądź zdecydowane działania ze strony Zachodu, plany zbliżenia do Ukrainy, Białorusi, Litwy, Łotwy i Estonii służyć miały przyspieszeniu tego procesu, jak również podkreśleniu polskich aspiracji do odegrania roli głównego moderatora przestrzeni środkowoeuropejskiej.

\section{Koncepcje środowiska paryskiej Kultury}

Na początku lat 50. uaktywnił się nowy ośrodek myśli politycznej podejmujący problem ustosunkowania się Polaków do relacji ze wschodnimi sąsiadami. Mowa tu o skupionym wokół Jerzego Giedroycia środowisku paryskiej Kultury. Gronu intelektualistów zgromadzonych wokół periodyku przyświecała idea wypracowania nowego, realistycznego podejścia do kwestii odzyskania wolności przez Polskę, tworzonego w oderwaniu od utartych schematów czy dogmatycznego podejścia. Ten stan rzeczy dotyczyć miał nie tylko kwestii czysto polskich, lecz także ustosunkowania się do relacji z sąsiadami, przede wszystkim tymi z najbliższego otoczenia Polski. Co charakterystyczne, od samego początku środowisko to lansowało pogląd, iż odzyskanie wolności i ułożenie współpracy z narodami sąsiadującymi z ówczesną Polską Rzecząpospolitą Ludową wymagać będzie znacznych wyrzeczeń ze strony samych Polaków. Egzemplifikacją takiego stanowiska było pytanie postawione przez redaktora naczelnego Kultury Aleksandrowi Bobkowskiemu, w którym to pytaniu Giedroyc stawial wyraźną tezę: Czy traktat ryski należy do kategorii sakramentów, czy też spokojnie podyskutujemy nad sensem tej granicy?

Otwarcie dyskusji nad kwestiami stanowiącymi do tej pory dogmat skutkowało pojawieniem się całego spektrum stanowisk przede wszystkim w kwestii koegzystencji z Ukraińcami i Litwinami. Choć w dalszym ciągu raczej niepodważalny był pogląd o potrzebie użycia Białorusinów, Ukraińców oraz narodów bałtyckich jako bariery oddzielającej Polskę od Rosji, to już kwestia, jak będzie wyglądał kształt terytorialny i granice (przede wszystkim granice z Polską) przyszłych okalających Rzeczpospolitą państw narodowych, pozostawać miała otwarta. W tym punkcie środowisko skupione wokół paryskiego periodyku szło wyraźnie pod prąd poglądów przedstawicieli tradycyjnych nurtów politycznych, traktujących powrót do granicy określonej traktatem z 1921 r. jako imperatyw nie podlegający dyskusji. Jakkolwiek przedstawiciele politycznych 
środowisk emigracyjnych odnotowywali głosy zamieszczane na łamach periodyku, dopóki ograniczały się one do poparcia dążeń niepodległościowych przede wszystkim Ukraińców, nie wzbudzały nadmiernych emocji. Zwłaszcza gdy jednocześnie eksponowano w nich tezę, iż powstanie niepodległego państwa ukraińskiego leży w żywotnym interesie Polski, w przyszłości stabilizować ma projektowaną federację.

Sytuacja ta zmieniła się w sposób zasadniczy, gdy na łamach pisma pojawiła się teza o konieczności wyrzeczenia się granicy ryskiej i akceptacji linii wytyczonej w Jałcie, jak również o rezygnacji z Lwowa i Wilna. Działania te miały skutkować pozyskaniem zaufania Ukraińców i Litwinów oraz zwiększeniem stopnia ich akceptacji dla rozwiązań federacyjnych po odzyskaniu niepodległości przez wszystkich potencjalnych uczestników projektowanego aliansu. Jakkolwiek w momencie prezentacji pierwszych enuncjacji, w których pojawial się element potrzeby akceptacji dla terytorialnych rozwiązań określonych w Jałcie i Poczdamie, poglądy zespołu redakcyjnego nie były do końca skrystalizowane, sam fakt dopuszczenia do dyskusji na temat porzucenia dążeń do odzyskania granicy ryskiej stanowił istotne novum w podejściu do zagadnienia. Jak już podkreślono, fakt mityzacji i dogmatyzacji przedwojennego rozgraniczenia Polski i Kraju Rad w znacznej mierze wynikał ze struktury niepodległościowego uchodźstwa. W społeczności wychodźczej zdecydowaną większość stanowili mieszkańcy kresów, dla których wizja powrotu do opuszczonych domostw pozostawała realnie artykułowanym dążeniem. Nie tylko dla tej grupy podważenie nienaruszalności granicy wschodniej stanowiło dogmat, którego odrzucenie utożsamiane było ze zdradą, a przynajmniej ze sprzeniewierzeniem się polskiej racji stanu.

Niezależnie od stopnia akceptacji lub negacji poglądów środowiska skupionego wokół Giedroycia zasługą redakcji Kultury pozostawała znacząca redefinicja koncepcji Międzymorza. Zasadniczą zgodność z wcześniej formułowanymi programami idea wypracowana w gronie redaktorów paryskiego pisma zachowywała w dwóch punktach: 1) przekonaniu o nieuchronności rozpadu Związku Sowieckiego w wyniku działań odśrodkowych; 2) iunctim między zdominowaniem przestrzeni środkowoeuropejskiej a odgrywaniem roli regionalnego mocarstwa. W tym ostatnim punkcie widać było wyraźne odwołania do retoryki Halforda Mackindera i jego adherentów oraz zaadaptowanie jej dla potrzeb stworzenia argumentacji geopolitycznej.

Twórców spod znaku Kultury wyraźnie odróżniało znaczące zawężenie przestrzeni, która ogniskować miała zainteresowania Polaków i która - zdaniem publikujących na łamach periodyku - winna zostać ograniczona do państw i narodów stanowiących najbliższe otoczenie ówczesnej Polski: Ukraińców, Litwinów i Białorusinów. To na tych trzech nacjach winny skupić się 
integracyjne wysiłki Polaków, co a priori oznaczało, iż w znacznie mniejszym stopniu uwzględniany był problem pozostałych krajów bałtyckich. Z czasem zresztą, jeśli kwestia Łotwy i Estonii w ogóle bywała dostrzegana przez to środowisko, stanowiła tło, względnie ilustrację, dla problemu koegzystencji z Litwinami. W przeciwieństwie do większości twórców polskiej myśli politycznej, którzy eksponowali pozytywne doświadczenia wynikające ze związków poszczególnych nacji z Rzecząpospolitą, paryżanie położyli nacisk na potrzebę uwzględnienia negatywnych doświadczeń historycznych. Ich zdaniem podstawą trwałości projektowanego aliansu Rzeczypospolitej, Ukrainy, Białorusi i Litwy była normalizacja stosunków z sąsiadami i załatwienie wszelkich spornych kwestii w taki sposób, aby nie powtórzyła się sytuacja z lat 1919-1921, kiedy to spór terytorialny spowodowal fiasko dążeń do urzeczywistnienia projektu federacji.

Nieprzypadkowo koncepcja koegzystencji Rzeczypospolitej z państwami ościennymi uzyskała w terminologii jej twórców miano koncepcji ULB. W ten sposób została podkreślona swoista hierarchia narodów, ku którym należało się zwrócić, chcąc uzyskać wcześniej nakreślone cele: 1) odzyskać pełną suwerenność; 2) trwale zniwelować zagrożenie ze strony Rosji (niezależnie od panującego w niej porządku ustrojowego). Naczelne miejsce w programie publicystów spod znaku Kultury zajęli Ukraińcy. Fakt ten nie mógł zresztą dziwić, biorąc pod uwagę jawne bądź nieświadome odwołania do mackinderowskich koncepcji z jednej strony, z drugiej zaś potencjał demograficzny i gospodarczy ziem ukrainnych, a także miejsce zajmowane przez Ukraińską Socjalistyczną Republikę Sowiecką w systemie społeczno-gospodarczym Kraju Rad.

Zresztą konsekwentne stanowisko o potrzebie uznania pełnych praw narodu ukraińskiego i artykułowania tego poglądu w przestrzeni międzynarodowej podkreślało sprzeciw redakcji nie tylko wobec skutków objęcia Ukraińców działaniami sowietyzacyjnymi, lecz również wobec poglądów wyrażanych przez środowisko narodowe, wskazujących powstanie Ukrainy jako zjawisko szkodliwe i zagrażające polskim interesom. $\mathrm{Z}$ tych też pozycji piętnowano na łamach pisma wszelkie projekty i dążenia do porozumienia Rzeczypospolitej z Rosją (Związkiem Sowieckim), których Ukraina musiałaby paść nieuchronną ofiarą. Przy odwołaniu się do argumentacji historycznej w opiniach środowiska Kultury dominował pogląd o potrzebie podkreślenia faktu i wyciągnięcia wniosków z doświadczenia, iż projekt urzeczywistnienia konstruktu mającego zapewnić Polsce bezpieczeństwo został zaprzepaszczony właśnie na Ukrainie.

Postrzeganie zjawisk geopolitycznych prowadziło natomiast do tezy, iż z punktu widzenia rosyjskiego właśnie posiadanie Ukrainy (a w dalszej kolejności również Litwy i Białorusi) stanowiło dla Rosji warunek konieczny do postrzegania jej $\mathrm{w}$ kategoriach mocarstwa. $\mathrm{Z}$ tejże konstatacji wynikało 
niezbicie, iż wyrwanie przestrzeni ukrainnych spod kurateli Moskwy leżało przede wszystkim w interesie Polski. Nie był to jednak warunek zapewnienia Rzeczypospolitej bezpieczeństwa $\mathrm{w}$ długofalowej perspektywie. Za takowy natomiast zostało uznane zapewnienie przede wszystkim Ukraińcom, lecz również Litwinom i Białorusinom, statusu równoprawnych partnerów.

Dopełnieniem tejże tezy pozostawało przekonanie, dobitnie i silnie artykułowane przez środowisko związane z pismem od końca lat 60. XX w., o konieczności poświęceń i akceptacji dla granicy wytyczonej w Jałcie. Według tezy akceptowanej przez większość publicystów Kultury, których głównym eksponentem pozostawał, ukrywający się pod pseudonimem londyńczyk, Juliusz Mieroszewski, obstawanie przy stanowisku albo Jałta, albo Ryga nosiło znamiona podwójnej buchalterii, czyniąc zamęt i wywołując nieprzychylne nastawienie wobec Polaków w świecie Zachodu, wśród potencjalnych partnerów zaś powodując nawrót obaw przed imperialnymi zakusami Polaków. Takie ujęcie sprawiało, iż środowisko skupione wokół Jerzego Giedroycia popadało w konflikt z ortodoksyjnymi reprezentantami ośrodka legalistycznego, przede wszystkim adherentami Piłsudskiego, jak Stefan Mękarski i Stanisław Paprocki (choć i tak na złagodzenie stanowiska tego ostatniego wpływało jego zatrudnienie w rozgłośni Radia Wolna Europa) czy - może w mniejszej mierze - z socjalistami Adama Ciołkosza. Niemniej jednak dzięki dysponowaniu pismem stanowiącym znaczną siłę oddziaływania (docierającego również do PRL) hasło, iż Polsce nie potrzeba nowych miast i nowych terytoriów - potrzeba jej natomiast chociażby minimum niezależności, zaczynało zdobywać coraz liczniejsze rzesze zwolenników. Zwłaszcza iż równolegle podnoszony był argumenty o korzyściach ekonomicznych wynikających z utrzymania granic zachodnich (łącznie z zawoalowaną sugestią, iż za odzyskanie Lwowa trzeba będzie zapłacić utratą Wrocławia), a także o optymalnej strukturze narodowościowej państwa umiejscowionego między Odrą a Bugiem, pozbawionego de facto mniejszości destrukcyjnie wpływających na spoistość makrostruktury.

W zbliżonych kategoriach postrzegane były przez przedstawicieli środowiska Kultury kwestie związane z relacjami polsko-litewskimi, przykładano do nich jednak znacznie mniejszą wagę niż do problemów związanych z Ukraińcami. Stan ten wynikał przede wszystkim z osądu opartego na kryteriach geopolitycznych i kulturowych. Litwa stanowiła oczywiście znacznie mniejszy organizm pod względem demograficznym i gospodarczym i sama - w przeciwieństwie do Ukrainy - nie mogła przesądzić o zachwianiu pozycji Rosji. Pod względem kulturowym, przede wszystkim językowym, Litwie było zdecydowanie dalej do związku z Polakami niż narodom słowiańskim: Ukraińcom i Białorusinom. Litwini mieli ponadto zajmować znacznie mniej afirmatywne stanowisko w kwestii aliansu z Polakami. Egzemplifikacją tego stanowiska był 
m.in. zamieszczony na łamach pisma tekst Jouzasa Girniusa ( $W$ poszukiwaniu dialogu polsko-litewskiego), w którym litewski publicysta polityczny określił unie Rzeczypospolitej z Wielkim Księstwem jako nieodpowiadające interesom Litwinów, zarzucając wprost Polakom dążenie do polonizacji narodów bałtyckich. Tekst ten, jak się wydaje, pozostawał kluczowy dla późniejszego ukształtowania się opinii emigracyjnych środowisk intelektualnych wobec Litwy.

Ujawnił przede wszystkim dwugłos w monolitycznym, jak mogłoby się wydawać, w swych opiniach środowisku piłsudczykowskim. Kiedy Jerzy Iwanowski podjął próbę obrony dziedzictwa i tradycji relacji polsko-litewskich, wskazując, iż związek z Koroną przyniósł Litwie przynależność do kultury Zachodu, a bez Polski Litwa skazana była na faktyczną germanizację, niemal w tym samym momencie Tadeusz Katelbach wskazał na potrzebę pogodzenia się z faktem uznania Wilna za historyczną stolicę Litwy i potrzebę zmiany emocjonalnego stosunku do tego miasta polegającej na akceptacji, iż w równej mierze gród nad Wilią był ośrodkiem litewskim i polskim (podobnie jak Lwów pozostawać miał wspólnym miastem Polaków i Ukraińców). Niemniej jednak dwugłos w środowisku, którego przedstawiciele uznawani byli za bezpośrednich politycznych spadkobierców wielkiej idei Piłsudskiego, wywołał skutek w postaci wzmożonej podatności na modyfikacje koncepcji, uznawanych do pewnego momentu za niewymagające znaczących rewizji. Zjawisko to widać było wyraźnie w publicystyce Kultury w stosunku do Litwinów, co przejawiło się w wyraźnym odżegnaniu się redakcji od ortodoksyjnego brzmienia tez koncepcji federacyjnej z lat 1918-1951 i w stopniowym przesuwaniu akcentów w kierunku propagowania wizji związku równoprawnych, wolnych narodów.

\section{Zamiast zakończenia. Krajowe refleksy emigracyjnych wizji}

Koncepcje wypracowane na emigracji stanowiły ważny element kształtowania się polskiej myśli politycznej w stosunku do najbliższych wschodnich sąsiadów, gdy społeczeństwo w Polsce w warunkach realnego socjalizmu pozbawione było możliwości nieskrępowanej wymiany poglądów. Od końca lat 60 . tezy wypracowane przez emigrantów politycznych, przenikając do środowisk opozycyjnych w kraju, w mniejszym bądź większym stopniu były implementowane do programów i założeń kontestatorów ładu politycznego, narzuconego Polsce w 1944/1945 r. Co jednak charakterystyczne, nawet wśród najradykalniej nastawionych środowisk, niekiedy wprost jak na przykład działacze Konfederacji Polski Niepodległej domagających się przekreślenia systemu jałtańskiego i postulujących powrót do systemu politycznego wprowadzonego na mocy konstytucji kwietniowej, kwestia rewizji granic nie stała się elementem 
programu politycznego. Natomiast niemal we wszystkich krajowych środowiskach politycznych, które zdołały wypracować własne rozwiązania programowe, może z wyjątkiem środowisk postnarodowych, podnoszona była kwestia harmonijnego ułożenia stosunków ze wschodnimi sąsiadami.

Krajowych opozycjonistów różniła w zasadzie kwestia spoistości wzajemnych relacji z Ukrainą, Białorusią i państwami bałtyckimi, ich charakter (bilateralne versus związek powiązań multilateralnych) oraz rozłożenie akcentów na cele (gospodarka versus bezpieczeństwo). Niemniej jednak w pewnym sensie spojrzenie na sowieckiego hegemona przez pryzmat związku z krajami ULB czy przestrzenią międzymorza miało też znaczenie praktyczne. Wizjonerstwo przedstawicieli emigracji wskazujących na nieuchronność rozpadu imperium i rozdarcia go po szwach narodowościowych okazało się po 1989 r. polityczną rzeczywistością. Natomiast wizja urzeczywistnienia ponadnarodowego związku narodów funkcjonujących w przestrzeni między Niemcami a Rosją do dzisiejszego dnia pozostaje niezrealizowanym testamentem ideowym i politycznym poprzednich pokoleń. 